\title{
EMOJI AND NONVERBAL COMMUNICATION: AN EXAMINATION OF SOCIAL NETWORKING SITES
}

\author{
Silas UDENZE*
}

Received: 30.01.2020 - Accepted: 21.09.2020

Udenze, S. (2020). Emoji and nonverbal communication: An examination of social networking sites. Etkileşim, 6, 36-49. doi: 10.32739/etkilesim.2020.6.74

This study complies with research and publication ethics.

\begin{abstract}
The study explored the phenomenon of nonverbal communication with its focus on emoji. Basically, the researcher examined five social networking sites (SNS) - (Facebook, WhatsApp, Instagram, Snapchat, and Twitter) in order to ascertain which of the SNS the research population uses emoji more often. Furthermore, the researcher explored the gender disparity in the use of emoji. The study employed the quantitative research method to achieve this end, precisely the survey technique. The hyperpersonal communication theory underpins and guides the research. Findings from the study indicate that a considerable number of the research population $(48.93 \%)$ considers WhatsApp's emojis as the most often used, followed by Facebook. Analysis of data further revealed that both genders- male and female use emoji evenly. The male, 71 respondents representing 50.35\% use emoji and 70 respondents; that is, $49.65 \%$ of the female equally use emoji for communication purposes. The study concludes that emojis are conduit pipes through which Internet users display their expertise in the manoeuvering of computer-mediated communication, specifically nonverbal communication; hence, researchers indicate that this calls for further scholarly investigation in this research domain.
\end{abstract}

Keywords: emoji, nonverbal communication, communication, social networking sites.

* Media Arts Scholar, University of Abuja,

udenzes@gmail.com, Orcid: 0000-0002-4785-2126

36 | ETKiLEşim | Üsküdar Üniversitesi | iletişim Fakültesi |Akademik Dergisi 


\title{
EMOJi VE SÖZSÜZ ILETIŞiM: SOSYAL AC̆ SITELERi ÜZERINE BIR INCELEME
}

\author{
Silas UDENZE*
}

Gönderim Tarihi: 30.01.2020 - Kabul Tarihi: 21.09.2020

Udenze, S. (2020). Emoji and nonverbal communication: An examination of social networking sites. Etkileşim, 6, 36-49. doi: 10.32739/etkilesim.2020.6.74

Bu çalışma araştırma ve yayın etiğine uygun olarak gerçekleştirilmiştir.

\section{Özet}

Bu çalışmada, emojilere odaklanarak sözsüz iletişim olgusu araştırılmıştır. Araştırmacı temel olarak araştırma topluluğunun hangi sosyal ağ sitelerini daha sık kullandığını belirlemek için beş sosyal ağ sitesini (SNS) - (Facebook, WhatsApp, Instagram, Snapchat ve Twitter) incelemiştir. Bununla birlikte, çalışmada emoji kullanımındaki cinsiyet eşitsizliği araştırılmıştır. Çalışmada bu amaca ulaşmak için nicel araştırma yöntemi kapsamında anket tekniği kullanılmıştır. Kişilerarası iletişim teorisi araştırmanın temelini oluşturmaktadır. Araştırmadan elde edilen bulgular, araştırma topluluğunun önemli bir kısmının (\%48.93) WhatsApp emojilerinin en sık kullanılan emojiler olduğunu ve bunu Facebook'un emojilerinin takip ettiğini düşündüğünü göstermektedir. Verilerin analizi sonucunda kadınların ve erkeklerin emojileri eşit olarak kullandığı ortaya çıkmıştır. Katılımcıların \%50,35'ini temsil eden 71 erkek ve \%49,65'ini temsil eden 70 kadın katılımcı; iletişim amacıyla, eşit derecede emoji kullanmaktadır. Bu çalışma emojilerin, internet kullanıcılarının bilgisayar aracılı, özellikle sözel olmayan iletişimde uzmanlıklarını sergiledikleri kanallar olduğu sonucuna varmıştır; bununla birlikte bu araştırma alanında daha fazla bilimsel araştırma yapılması gerekmektedir.

Anahtar Kelimeler: emoji, sözsüz iletişim, iletişim, sosyal ağ siteleri.

* Medya Araştırmacısı, Abuja Üniversitesi,

udenzes@gmail.com, Orcid: 0000-0002-4785-2126 


\section{Introduction}

Communication is essential to all facets of life. All living things, biologically communicate. It is a phenomenon that facilitates the exchange of ideas or information amongst living creatures. In human beings, communication is elaborately developed compared to lower creatures- animals. In a layman's language, communication means the exchange of information or thought between individuals. Merriam Webster's Collegiate Dictionary defines communication as a process by which information is exchanged between persons through a system of symbols, signs, or behaviour. From the above definition, it is apparent that there are different mediums of communication, and signs and symbols are an integral part of it. Albeit, there is a general belief that it is not only the significance of 'what' is communicated that is essential but also how it is communicated. This statement is synonymous to the famous $5 \mathrm{Ws}$ and $1 \mathrm{H}$ in journalism studies. The manner of communication includes verbal communication, which entails the use of spoken words or speech. Nonverbal communication features things like facial expression, body posture, breathing rhythm, outer appearance, and various others (Hinz, 2015). In other words, it is a means of communicating without spoken words. It usually happens through individuals' behaviours, actions, expressions, signs, and symbols (Kumari and Gangwar, 2018). Birdwhistell (1970) argues that $65 \%$ of communication is through nonverbal communication, while only $35 \%$ is derived through interaction in word.

Today, communication is predominantly transmitted through the Internet, and a considerable percentage of the information communicated is carried out through electronic devices like desktop computers, laptops, smartphones, tablets, ipads etc. These devices enable the installation of social media applications such as Facebook, Instagram, WhatsApp, Wechat, Snapchat, among others. These social media platforms allow users to exchange messages both fast and synchronously. There is a feature that distinguishes social media platforms from other traditional messaging services like SMS- the immense abundance of emojis. Scholars (Derks, Fischer and Bos, 2008; Luor et al, 2010; Jibril and Abdullah, 2013) have argued that emoji may be described as a substitute for facial expressions.

Pictorial communication has evolved from time immemorial. In North Africa, during the ancient Egyptian civilization, the hieroglyph held sway. In Nigeria, specifically in the Southern part of the country, the Insibidi was a popular form of pictorial communication. From the previous assertions, it is apparent that the use of images for communication has been in existence before the ега of a technological boom. Before emoji became popular, there is a form of image communication called emoticon. An emoticon is achieved by combining different punctuation marks- smiley face (:-)). Dresner and Herring (2010) describe emotions as emotion icons. The authors refer to it as graphic signs, such as the smiley face, that often accompany computer-mediated textual communication. A group of researchers initially developed emoticon at Carn-

\section{8 | ETKíleşim |Yıl3|Sayı 6| Ekim 2020}


egie Mellon by way of a joke in 1982 (Brisson, 2015). The Japanese metamorphosed emoticon. They created another version of it that connotes ideas with emoticons that could be read simultaneously with text- the Japanese smiley faces, called kaomoji (^_^). It allows users to embellish and eventually add on other symbols to portray physical motions or represent other objects, such as flowers or animals (Brrison, 2015).

Li and Yang (2018) writes that emoji is a Japanese word, which means 'picture letter'. It is a small digital picture or pictorial symbol that represents a thing, emotions, or a concept, etc., used in text messages and means of electronic communications. Oxford Dictionary (2012), defines emoji as a small digital image or icon used to express an idea or emotion in electronic communication. Emojis are used almost in the same way as are emoticons and exist in different genres, including facial expressions, gestures, known objects, places

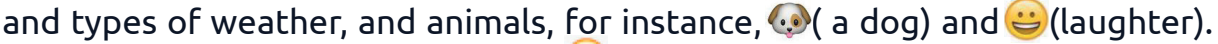
In 2015 Oxford Dictionaries named (face with tears of joy) instead of text words as its Word of the Year (Li and Yang, 2018). Emoji has become an inevitable part of the Internet Age communication, and scholars must begin to notice their functions in the communication sphere.

\section{Objectives of the Study}

This study investigates emoji on five different social networking sites- Facebook, WhatsApp, Instagram, Snapchat and Twitter with the main objective of ascertaining which of the SNS the research population uses emoji more often. Furthermore, specifically, other objectives of the study include:

1. To ascertain the gender disparity in the use of emoji.

2. To find out how often the population uses emoji.

3. To investigate their reasons for using emoji

\section{Research Questions}

1. What is the gender difference in the population's use of emoji?

2. How often does the population use emoji?

3. What is the reason for the population's use of emoji?

\section{Literature Review}

Formal research on nonverbal communication is rooted in the Victorian Era. Charles Darwin is perhaps the pioneer scholar to systematically study how we use our bodies to communicate in the Expression of the Emotions in Man and Animals (Darwin, 1874). In the social sciences, a new wave of systemat- 
ic research into nonverbal communication was started by Ray Birdwhistell's work on 'Kinesics' in the 1950s and Edward Hall's work on 'Proxemics' in the 1960 s, which in turn led to a surge of public interest in 'body language' with sensationalist works like Fast's (1970) Body Language, which teaches readers how to penetrate the personal secrets of strangers, friends and lovers by interpreting their body movements, and to make use of powers. Innocent and Haines (2007), define nonverbal communication as wordless communication, including gesture, body language, facial expression, intonations of speech, and clothing. In this digital age, the study of nonverbal communication, specifically, emoji is gaining attention among scholars.

Emoji is originally designed as a carrier of affective states and emotions, containing nonverbal information that in real settings is communicated through facial expression and other physical indicators (Dresner and Herring, 2010; Sakai, 2013; Maíz-Arévalo, 2015). Emoji, which includes small pictures from the smiling face of a 'blue whale' to 'sarcastic side-eye', increase the ability of the messenger to communicate more fully and successfully (Stryker, 2014). Emoji can increase the understanding of other conversational aspects such as tone, attitude, intent, and emotion in computer-mediated communication (Lo, 2008; Prazak and Burgund, 2014). In the same light, Mitchell (1986) argues that a visual cue combined with texts was superior to texts alone in the creation of a more positive attitude in communication.

Lupyan and Dale (2016) submit that four groups of Instagram posts increased in emoji use by $30 \%$ to $40 \%$ in 2015 compared with that in the last 2 to 3 years. Also, the scholars found that there was a gradual decrease in the use of text-based communication, which suggests that emojis are replacing the functions served by text-based contents. The findings reveal that textbased communication is gradually giving way to emojis. Thompson and Foulger (1996) argue that hostile verbal messages with emojis were of a different hostility level from those without. From the Thompson and Foulger's assertion, it is apparent emojis clarify, and explain statements.

Provine, Spencer and Mandell (2007) conducted a study on the positioning and functions of emojis in text-based communication. Provine and his colleagues classified emojis, as additional or complementary information to textbased communication. The categorizations include:

1. Emojis which constitute the only content of the message or 'naked emojis'.

2. Emojis that are placed at the beginning or the end of the message (the most frequent).

3. Emojis that are inside the message.

Hinz (2015) asserts that as the people cannot see or hear each other, they have to signal their mood otherwise, and this is achieved by purposely insert-

40 | ETKíleşim | Yıl3|Sayı 6 | Ekim 2020 
ing emojis or emoticons at a specific position of their text. The author buttressed his argument by citing Albert Mehrabian, a renowned psychologist, claiming that the human brain processes image 60,000 times faster than written text. Similar to Thompson and Foulger's contribution, Provine et al., and Hinz's studies point to the belief that emojis serve as modifiers of text-based messages. Further, based on the analysis of 500 messages on WhatsApp, Hinz (2015) found that a colleague to colleague conversation did not contain as many emojis as the friend to friend conversations. This is because of the lower degree of social closeness between the colleagues. In total, $50 \%$ of all messages contained at least one emoji, WhatsApp users seem to use emojis frequently.

Back to the taxonomy of emoji, Luor, Wu, Lu and Tao (2010) categorize emoji into- expressing feelings, modifying the verbal message, and expressing humour. While Kavanagh's (2010) classification seemed more elaborate, that is, (1) in rapport building; (2) to soften requests; (3) devices of modesty; (4) hedging devices; (5) humour; (6) to help convey emotion; (7) emphatic use; and (8) lexical use; (9) positive politeness strategies.

Emojis are the fastest growing language in history (Emogi Resarch Team, 2015). In the Emoji Report, various factors were studied to ascertain factors responsible for this growth. It was uncovered that the rise in the usage of smartphones and instant messaging applications are major contributors to Emoji usage. With this, communications have become shorter, making emojis universal language that promotes universality. 'Emoji Report' further found that instant messaging applications update the emojis regularly to reflect societal changes. Sampietro (2015) opines that stand-alone emojis or what Provine et al. (2007) described as naked emoji are frequently used and are a common thing among users, as the author's findings showed that they are self-explanatory and easy to use while communicating. Sampietro analyzed WhatsApp chats and commented that emojis are used in socially relevant vocabularies, and acronyms and slangs also confirm the similar nature of emoji usage supporting the environment of expected social reactions in the conversations.

Despite studies conducted on emojis, there are still limitations in the existing research domain. Broadly, most empirical studies (Provine et al. 2007; Thompson and Foulger, 1996; Luor et al. 2010; Hinz 2015) focused on one the taxonomy of emojis and its function as a modifier. To the best of the researcher's scholarly knowledge, there has not been a study that considered these SNS. Thus, this study investigates emoji on five (Facebook, WhatsApp, Instagram, Snapchat and Twitter) social networking sites in order to ascertain which of it the research population uses emoji more often, and further explored gender disparity in the use of emoji. 


\section{Research Methodology}

The present study adopts the quantitative research method, specifically a survey. The population of the study is the youths, a protestant church in Wuse, Abuja, Nigeria. Purposively, and for the sake of convenience the author sampled 144 youths from the church. The current study complied with the research ethics of my institution, and the participants were informed before implementing the survey. Besides, the respondents voluntary appended their consents to participate in the study beforehand. The study questionnaire was administered face-to-face after church services and during youth fellowships. In analyzing data, Simple Percentage Table (SPT) was adopted for ease and flexible analysis. However, due to the manageable sample size of the study, the analysis data was carried out based on 141 duly returned and valid questionnaires.

\section{Theoretical Framework}

In the early years of the Internet, it was assumed that computer-based communication was not interactive. During the period, users were constrained by the limits of the computer's text-based nature, which was contrasted with the rich meaning of body language, voice, and facial cues of face-to-face communication. Today, the reward we get when we get validated by likes, claps, comments, and other nonverbal cues can be described with the hyperpersonal communication theory.

Joseph Walther (1996) is credited for propounding the theory after extensive research on computer-mediated communication. The theory is an interpersonal communication model that describes how computer-mediated communication (CMC) can become hyperpersonal because it exceeds face-to-face interaction, affording communicators a host of communicative advantages over traditional face-to-face interaction. Walther (1996) asserts that hyperpersonal communication is more socially desirable than we tend to experience in parallel face-to-face interaction. Furthermore, Walther argues that computer-mediated communication focuses on personal and relational optimisation because they are unfettered by unwanted cues or multiple conversational demands. Kumari and Gangwar (2018) wrote that in hyperpersonal theory, nonverbal cues allow the communicator to determine their choice of cues for communication. Compared to face-to-face communication, a hyperpersonal message sender has a greater ability to develop and edit self-presentation strategically, enabling a selective and optimised presentation of one's self to others.

The social media afford communicator a plethora of nonverbal communication cues. Consequently, people get hyperpersonal in cyberspace because it satisfies relationship needs, and numerous social norms and boundaries already govern face-to-face interaction. Today, cyberspace allows us to commu-

42 | ETKíleşim | Yıl3|Sayı 6| Ekim 2020 
nicate in a new and satisfying way, and users, especially the youths, are taking advantage of it.

\section{Analysis of Findings}

The high return percent of questionnaires was possible because the researcher gave detailed attention in engaging the respondents on the aim of the study, assuring them of their privacy and patiently waited for them to read and answer the questionnaires before retrieving them. Preliminary data on demographic analysis indicates that $47.48 \%$ of the respondents are male, while $52.52 \%$ are female. Also, $39.00 \%$ of the respondents were between 15 and 25 years, $41.13 \%$ were between 26 and 35 , and $19.85 \%$ were between 36 and above. Further, $10.63 \%$ of the respondents had primary school qualification as their highest educational qualification; $26.95 \%$ had Senior School Certificate (SSCE) or its equivalent; $22.69 \%$ had diploma; $45.31 \%$ had university degrees or Higher National Diploma (HND), and $7.80 \%$ had postgraduate qualifications.

Table 1. Perception and usage of emojis on social media platforms

\begin{tabular}{|c|c|c|c|c|c|}
\hline $\begin{array}{l}\text { Do you } \\
\text { use emoji } \\
\text { on social } \\
\text { media } \\
\text { platforms } \\
\text { while inter- } \\
\text { acting? }\end{array}$ & Responses & $\begin{array}{l}\text { Do you feel } \\
\text { including } \\
\text { emoji in } \\
\text { your chat } \\
\text { enhances } \\
\text { message? }\end{array}$ & Responses & $\begin{array}{l}\text { Do you } \\
\text { include } \\
\text { emoji on } \\
\text { official } \\
\text { message? }\end{array}$ & Responses \\
\hline Always & $\begin{array}{c}47.51 \% \\
N=67\end{array}$ & Yes & $\begin{array}{c}43.92 \% \\
N=62\end{array}$ & Yes & $\begin{array}{c}34.04 \% \\
N=48\end{array}$ \\
\hline Rarely & $\begin{array}{c}18.43 \% \\
N=26\end{array}$ & No & $\begin{array}{c}26.95 \% \\
N=38\end{array}$ & No & $\begin{array}{c}42.55 \% \\
N=60\end{array}$ \\
\hline Sometimes & $\begin{array}{c}29.07 \% \\
N=41\end{array}$ & Maybe & $\begin{array}{c}29.07 \% \\
N=41\end{array}$ & Sometimes & $\begin{array}{c}23.40 \% \\
N=33\end{array}$ \\
\hline Never & $\begin{array}{c}4.96 \% \\
N=7\end{array}$ & Total & $\begin{array}{c}100 \% \\
N=141\end{array}$ & Total & $\begin{array}{c}100 \% \\
N=141\end{array}$ \\
\hline Total & $\begin{array}{c}100 \% \\
\mathrm{~N}=141\end{array}$ & & & & \\
\hline
\end{tabular}

The table indicates that the majority of the respondents always use emoji (47.51\%) while interacting. $18.43 \%$ rarely use it; $29.07 \%$ use it sometimes, and 
4.96\% claimed they do not use it. Furthermore, the data in the table shows that the respondents believe that including emoji in their interaction on social media platforms enhances the message they convey. $43.92 \%$ expressed the other thought. However, $29.07 \%$ feels that somehow, inserting emoji in their message enhances the meaning of the information, and $26.95 \%$ avers that the practice of including emoji in a message does not improve its communicability. In the last part of Table 1, a significant portion of the population, that is, $42.55 \%$, reiterates that they do not use emoji in official messages. $23.40 \%$ opines that sometimes they use emoji in official, probably depending on the situation, and $34.04 \%$ claims that they adopt emoji in formal interaction.

Table 2. Respondents' diverse use of emojis and gender disparity in its usage

\begin{tabular}{|c|c|c|c|c|c|}
\hline $\begin{array}{c}\text { Are you } \\
\text { restricted } \\
\text { or curtailed } \\
\text { to use } \\
\text { emoji while } \\
\text { interacting } \\
\text { with } \\
\text { friends and } \\
\text { families? }\end{array}$ & Responses & $\begin{array}{l}\text { On which } \\
\text { of these } \\
\text { platforms } \\
\text { do you } \\
\text { often use } \\
\text { emoji? }\end{array}$ & Responses & $\begin{array}{l}\text { Analysis } \\
\text { of gender } \\
\text { disparity in } \\
\text { the use of } \\
\text { emoji }\end{array}$ & Responses \\
\hline Yes & $\begin{array}{l}9.21 \% \\
N=13\end{array}$ & Facebook & $\begin{array}{c}29.07 \% \\
N=41\end{array}$ & Male & $\begin{array}{c}49.64 \% \\
N=70\end{array}$ \\
\hline No & $\begin{array}{l}78.01 \% \\
N=110\end{array}$ & WhatsApp & $\begin{array}{c}48.93 \% \\
N=69\end{array}$ & Female & $\begin{array}{c}50.35 \% \\
N=71\end{array}$ \\
\hline Sometimes & $\begin{array}{c}12.76 \% \\
N=12\end{array}$ & Instagram & $\begin{array}{c}10.63 \% \\
N=15\end{array}$ & Total & $\begin{array}{c}100 \% \\
N=141\end{array}$ \\
\hline Total & $\begin{array}{c}100 \% \\
N=141\end{array}$ & Snapchat & $\begin{array}{c}4.96 \% \\
N=7\end{array}$ & & \\
\hline & & Twitter & $\begin{array}{c}6.38 \% \\
N=9\end{array}$ & & \\
\hline & & Total & $\begin{array}{c}100 \% \\
N=141\end{array}$ & & \\
\hline
\end{tabular}

Data from the above table reveals that a vast number $(78.01 \%)$ of the population are not restricted or curtailed in using emoji on social network sites while interacting with friends and families. However, $12.76 \%$ of the population asserts that they are curtailed not to use emoji in some situations while discussing with their families and friends, and $9.21 \%$ said they curtailed themselves on using emoji while interacting with their friends and families. Also, the reveals users' preference for emoji in the selected five social networking sites for the study. The analysis indicates that a smaller percentage of the 
respondents, that is, $4.96 \%$ prefer emojis on Snapchat. A considerable number of the research population (48.93\%) considers WhatsApp's emojis as the most preferred. Second, to WhatsApp is Facebook; $29.07 \%$, Instagram 10.63\%, and Twitter is $6.38 \%$. Finally, it is revealed that both genders use emoji almost evenly. The table shows that males, 71 respondents representing $50 \%$ use emoji for communication while 70 respondents, that is, $49.64 \%$, use emoji for communication purposes.

Table 3. Displaying respondents' reasons for using emojis

\begin{tabular}{|l|c|}
\hline Why do you use emoji? & Responses \\
\hline To build rapport & $2.83 \%$ \\
\hline \multirow{2}{*}{ For humour } & $\mathrm{N}=4$ \\
\hline \multirow{2}{*}{ To convey emotion } & $19.85 \%$ \\
& $\mathrm{~N}=28$ \\
\hline \multirow{2}{*}{ For emphasis } & $21.98 \%$ \\
\hline \multirow{2}{*}{ To save time used in typing text } & $\mathrm{N}=31$ \\
\hline \multirow{2}{*}{ Total } & $28.36 \%$ \\
& $\mathrm{~N}=40$ \\
\hline
\end{tabular}

\section{Discussion of Findings}

The use of emojis in the social media platform is becoming a standard feature; this is the reason most social media sites update their emojis regularly. From the analysis in Table 2, it is apparent that respondents consistently use WhatsApp emojis. WhatsApp has grown to become the preferred social media site. The findings of this study are synonymous with a recent study (Newman et al, 2019) by the 'Reuters Digital News Report', which affirms that people are turning away from Facebook and WhatsApp is becoming the leading source for social communication in many countries. Besides, WhatsApp is a media-rich social media platform. Its multiple media functionality may engender it to users. The finding in table 1 may also be linked to the diverse categories of emojis on WhatsApp. Hinz (2015) submits that there is a considerable number of emojis on WhatsApp, which are divided into five categories. These categories are not titled by words but by images. The first category, Face and Body, includes 378 emojis, which are several facial expressions. The second and largest cat- 
egory, Various, contains 230 highly diverse emojis. In the third category, Nature, there are 116 emojis depicting animals, plants, moon constellations, and weather conditions. The fourth category is known as Traffic and Flags, and it encompasses 147 emojis, which resemble different kinds of houses or institutions, various types of public transport, and the flags of different countries. In the fifth category, Symbols, there are 207 emojis.

The current study reveals that the population uses emoji always (43.92\%). This answers one of the research objectives of the study. However, the gender disparity in the use of emoji indicates that both male and female adopts the use of emoji evenly. Other studies (Ananth, n.d) found that unlike males, females use emoji more often. Ananth's study revealed that women most sought out gratification for using emoji were to express themselves better. Before now, it is known that females use emoji more often than males. The findings of the study indicate a remarkable landmark in the study of emoji. Besides, the study found that the population uses emoji in order to emphasize their message while interacting just as Kavanagh's (2010) assertion, and it also saves the time of typing text.

\section{Conclusion}

The study explored the users' use of emojis on five social networking sites and gender disparity in the use of emoji. Emojis, like original smiley, help people in digital spheres to cope emotionally with the experience of building and maintaining social sites within hierarchical technological platforms and unjust economic systems that operate far outside of their control (Stark and Crawford, 2015). A significant conclusion from this study is that: respondents often use emojis on WhatsApp compared to other SNS adopted for the study. This is connected to the media-rich emojis on WhatsApp. Secondly, the study proved that men are catching up with their women counterparts in the use of emojis for nonverbal communication. Emoji serves as a conduit pipe through which Internet users display their expertise in the manoeuvering of computer-mediated communication, specifically nonverbal communication; hence, the researcher calls for further scholarly exploration in this research domain.

\section{References}

Birdwhistell, R. L. (1952). Introduction to kinesics: An annotation system for analysis of body motion and gesture. Louisville, KY: Louisville University Press.

Brisson, C. (2015). Hieroglyphs at our fingertips: Language, semiotics and communication through emoji. https://www.academia.edu/12568625/Hieroglyphs_at_Our_Fingertips_Language_Semiotics_and_Communication_ through_Emoji.

46 | ETKiLeşim | Yıl3|Sayı 6| Ekim 2020 
Derks, D., Fischer, A. H., Bos, A. E. (2008). The role of emotion in computer mediated communication: A review. Computers in Human Behavior, 24, 766-785.

Dresner, E. and Herring, S.C. (2010). Functions of the nonverbal in CMC: Emoticons and illocutionary force. Communication Theory, 20, 249-268.

Emogi Research Team. (2015). Emoji report. https://cdn.emogi.com/docs/reports/2015_emoji_report.pdf.

Fast, J. (1970). Body language. New York: Neirenberg.

Hinz, L. (2015). The functions of emoticons and pictograms in instant messengers. Living Linguistics, 92-103.

Innocent, T. and Haines, S. (2007). Nonverbal communication in multiplayer game worlds. Proceedings of the 4th Australasian Conference on Interactive Environment. RMIT University, Melbourne, Australia.

Jibril, T. and Abdullah, M. (2013). Relevance of emoticons in computer-mediated communication contexts: An overview. Asian Social Science, 9(4), 201-207.

Kumari, R. and Ganagwar, R. (2018). A critical study of digital nonverbal communication in interpersonal and group communication: In context of social media. International Journal of Communication and Media Studies (IJCMS, 8(4) 1-12.

Li, L. and Yang, Y. (2018). Pragmatic functions of emoji in internet based communication---a corpus-based study. Asian-Pacific Journal of Second and Foreign Language Education, https://doi.org/10.1186/s40862-018-0057-z.

Luor, T., Wu, L. L., Lu, H. P. and Tao, Y. H. (2010). The effect of emoticons in simplex and complex task-oriented communication: An empirical study of instant messaging. Computers in Human Behavior, 26(5), 889-895.

Lupyan, G. and Dale, R. (2016). Why are there different languages? The role of adaptation in linguistic diversity. Trends in Cognitive Sciences, 20(9), 649-660.

Maíz-Arévalo, C. (2015). Typographic alteration in formal computer-mediated communication. Procedia - Social and Behavioral Sciences, 212, 140-145.

Mitchell, A. A. (1986). The effect of verbal and visual components of advertisements on brand attitudes and attitude toward the ad. Journal of Consumer Research, 13, 12-24.

Newman, N., Fletcher, R., Kalogeropoulos, A. and Nielsen, R.K. (2019). Reuters Institute digital news report 2019. Reuters Institute. https://reutersinstitute. politics.ox.ac.uk/sites/default/files/2019-06/DNR_2019_FINAL_0.pdf.

Provine, R. R., Spencer, R. J. and Mandell, D. L. (2007). Emotional expression online emoticons punctuate website text messages. J Language Social Psychology, 26(3), 299-307.

Sakai, N. (2013). The role of sentence closing as an emotional marker: A case of Japanese mobile phone e-mail. Discourse, Context and Media, 2, 149-155.

Sampietro, A. (2015). Are emoji the new punctuation marks? Insights from Whatsapp chats. Approaches to Digital Discourse Analysis (1-18). Valencia. 
Stark, L. and Crawford, K. (2015). The conservatism of emoji: Work, affect, and communication. Sage Publication.

Thompson, P. A. and Foulger, D. A. (1996). Effects of Pictographs and quoting on flaming in electronic mail. Computers in Human Behavior, 12, 225-243.

Walther, J. B. (1996). Interpersonal effects in computer-mediated interaction: A relational perspective. Communication Research, 19(52), 52-90.

Participant informed consent : Participants were informed before the data collection and they were asked to sign a form of consent.

Conflict of interest: There are no conflicts of interest to declare.

Financial support : No funding was received for this study.

Onam bilgisi: Katılımcılar işlem öncesinde bilgilendirilmiş, onam formu imzalatılmıştır.

Çıkar çatışması : Çıkar çatışması bulunmamaktadır.

Finansal destek: Finansal destek bulunmamaktadır.

48 | ETkileşim |Yıl 3|Sayı 6| Ekim 2020 
